\title{
Conversion of the Mycotoxin Patulin to the Less Toxic Desoxypatulinic Acid by the Biocontrol Yeast Rhodosporidium kratochvilovae Strain LS11
}

\author{
Raffaello Castoria, ${ }^{*+,}, \nabla$ Luisa Mannina, ${ }^{\neq, \bigcirc}$ Rosa Durán-Patrón, ${ }_{\sharp}^{\S}$ Francesca Maffei,, Anatoly P. Sobolev, ${ }^{\perp}$ \\ Dario V. De Felice, ${ }^{\dagger}$ Cristina Pinedo-Rivilla, ${ }^{\S}$ Alberto Ritieni, ${ }^{\#}$ Rosalia Ferracane, ${ }^{\#}$ and Sandra A. I. Wright ${ }^{+}$ \\ ${ }^{\dagger}$ Dipartimento di Scienze Animali, Vegetali e dell’Ambiente, and ${ }^{\ddagger}$ Dipartimento di Scienze e Tecnologie Agro-Alimentari, Ambientali e \\ Microbiologiche, Università degli Studi del Molise, Via F. De Sanctis snc, 86100 Campobasso, Italy \\ ${ }_{\S}^{\S}$ Departamento de Química Orgánica, Facultad de Ciencias, Universidad de Cádiz, Apdo 40, 11510 Puerto Real, Cádiz, Spain \\ "Dipartimento di Farmacologia, Università degli Studi di Bologna, Via Irnerio 48, 40126 Bologna, Italy \\ ${ }^{\perp}$ Istituto di Metodologie Chimiche, CNR, Laboratorio di Risonanza Magnetica “Annalaura Segre”, 00015 Monterotondo Stazione \\ (Rome), Italy \\ \#Dipartimento di Scienza degli Alimenti, Università di Napoli “Federico II”, Parco Gussone, 80055 Portici, Italy \\ Supporting Information
}

\begin{abstract}
The infection of stored apples by the fungus Penicillium expansum causes the contamination of fruits and fruit-derived products with the mycotoxin patulin, which is a major issue in food safety. Fungal attack can be prevented by beneficial microorganisms, so-called biocontrol agents. Previous time-course thin layer chromatography analyses showed that the aerobic incubation of patulin with the biocontrol yeast Rhodosporidium kratochvilovae strain LS11 leads to the disappearance of the mycotoxin spot and the parallel emergence of two new spots, one of which disappears over time. In this work, we analyzed the biodegradation of patulin effected by LS11 through HPLC. The more stable of the two compounds was purified and characterized by nuclear magnetic resonance as desoxypatulinic acid, whose formation was also quantitated in patulin degradation experiments. After R. kratochvilovae LS11 had been incubated in the presence of ${ }^{13} \mathrm{C}$-labeled patulin, label was traced to desoxypatulinic acid, thus proving that this compound derives from the metabolization of patulin by the yeast. Desoxypatulinic acid was much less toxic than patulin to human lymphocytes and, in contrast to patulin, did not react in vitro with the thiol-bearing tripeptide glutathione. The lower toxicity of desoxypatulinic acid is proposed to be a consequence of the hydrolysis of the lactone ring and the loss of functional groups that react with thiol groups. The formation of desoxypatulinic acid from patulin represents a novel biodegradation pathway that is also a detoxification process.
\end{abstract}

KEYWORDS: patulin, metabolization, desoxypatulinic acid, detoxification, biocontrol yeast

\section{INTRODUCTION}

Patulin is a mycotoxin that is synthesized by a number of fungi. It is a polyketide secondary metabolite, which represents a serious health hazard and is a major issue for food safety. ${ }^{1}$ Its major producer, the fungus Penicillium expansum Link., is an important postharvest pathogen of apples and pears and causes the accumulation of patulin in infected pome fruits. This leads to the contamination with patulin in pome fruit-derived juices and baby foods, consumed by children, who have a low tolerance level to patulin. ${ }^{2}$ Patulin has diverse toxic effects such as immunosuppression, embryo and maternal toxicity in mice, and genotoxicity to cultured human cells. ${ }^{3-5}$ The mechanism of patulin toxicity has been proposed to be due to its reactivity with thiol-bearing molecules such as the important cellular antioxidant glutathione. ${ }^{6,7}$ Acute symptoms caused by patulin in humans are gastritis and nausea. ${ }^{2}$ Therefore, many countries, including the U.S. and those of the European Union, have established maximum tolerable levels of patulin contamination for fruit-derived products. ${ }^{8,9}$

The most effective way of avoiding mycotoxin contamination is to stop the fruit from being attacked by mycotoxin-producing fungi, through the appropriate handling of fruit and the treatment with fungicides. ${ }^{2}$ Fungicide treatments cannot completely prevent infection by $P$. expansum. Furthermore, selecting healthy fruits on an industrial scale does not ensure the absence of patulin in the final product. ${ }^{10}$ Detoxification of mycotoxins (i.e., the conversion or degradation of mycotoxins to less toxic compounds) in food for human consumption has recently gained interest, with particular focus on mycotoxins present in beverages that derive from crops that are susceptible to the attack of mycotoxigenic pathogens. ${ }^{11,12}$

Over the past two decades, research interest on preventive strategies such as the biocontrol of postharvest pathogenic fungi by utilizing harmless bacteria and yeasts has steadily increased, as has public concern regarding fungicide residues in food. Some biocontrol agents have been developed for commercial use. ${ }^{13,14}$

Received: March 25, 2011

Accepted: September 19, 2011

Revised: September 17, 2011

Published: September 19, 2011 
The mechanisms of action of biocontrol agents have been examined, with the final goal to understand how biocontrol agents operate and to improve their efficacy. ${ }^{13,15-17}$ Preharvest application of biocontrol agents for control of postharvest diseases has been proposed and tested. ${ }^{18}$ Interestingly, some biocontrol agents appear to have both the ability to prevent fungal infections on fruit and the potential for degrading the mycotoxins that are produced by these same fungi. Strains of Aureobasidium pullulans effectively protected wine-grapes from infection by Aspergillus carbonarius in the vineyard and prevented their subsequent contamination with ochratoxin A. They were also able to degrade the mycotoxin to the less toxic compound ochratoxin $\alpha$ in synthetic medium and fresh grape must. ${ }^{19}$ Another biocontrol yeast, strain LS11 of the basidiomycete Rhodosporidium kratochvilovae [a strain that was formerly designated Rhodotorula glutinis, but was renamed $R$. kratochvilovae following the analysis of the sequence data of the internal transcribed spacer (ITS) region (unpublished data)], can prevent apples from the attack of postharvest rot fungi ${ }^{20}$ and lower patulin contamination in stored fruit. ${ }^{21}$ Less patulin accumulated in apples that had been pretreated with the yeast and infected by $P$. expansum than in non-yeast-treated, infected fruits. ${ }^{21}$ Furthermore, strain LS11 can resist very high concentrations of patulin $(500 \mu \mathrm{g} / \mathrm{mL})$ and is able to metabolize this mycotoxin under aerobic conditions, leading to the formation of two products with $R_{f}$ (retention factor) 0.46 and $R_{f} 0.38$, as detected by TLC. ${ }^{21}$ The compound(s) with $R_{f} 0.46$ appears to be more stable and is most likely the major final product(s) of the degradation process, because it is present at the end of the degradation process, when the other product is no longer detectable (unpublished data). Preliminary observations indicated that the two biodegradation products were less toxic than patulin to Escherichia coli (unpublished data). However, their toxicity to eukaryotic cells, such as human cells, is unknown.

Metabolization of patulin to other unknown compounds has been reported previously. Several research groups also observed that strains of Saccharomyces cerevisiae were able to cause the disappearance of patulin from fermented apple juice over time. ${ }^{22,23}$ In recent years, the degradation products have been identified in the case of the biodegradation carried out by the fermentative yeast Saccharomyces cerevisiae in anaerobic conditions. ${ }^{12}$ The final products are two different isomers of ascladiol, E-ascladiol and Z-ascladiol. E-Ascladiol is the predominant degradation compound. Not much data exist on the toxicity of ascladiol. It is allegedly less toxic than patulin but still retains a quarter of the toxicity of patulin, and can be considered a mycotoxin in itself. ${ }^{24}$ The results of TLC analyses suggest that the major product of aerobic patulin degradation by the biocontrol yeast $R$. kratochvilovae LS11 has an $R_{f}$ value of 0.46 , which is distinct from that of ascladiol. ${ }^{21,25}$ Therefore, a novel pathway could be responsible for the metabolization of patulin by $R$. kratochvilovae LS11.

In this work, we analyzed by HPLC the metabolization of patulin operated by $R$. kratochvilovae LS11, characterized by NMR the major metabolite produced, and analyzed by HREIMS isotope incorporation into this compound following incubation of strain LS11 with ${ }^{13} \mathrm{C}$-labeled patulin, to provide unequivocal evidence that the produced metabolite derives from the biodegradation of patulin by the yeast. Furthermore, we confirmed that a detoxification had occurred by comparing the toxicity of the new compound to that of patulin in a bioassay based on cultured human lymphocytes.

\section{MATERIALS AND METHODS}

Materials. A commercial standard of patulin was purchased from Sigma-Aldrich (Milan, Italy). Immediately prior to use, weighed aliquots of the mycotoxin were dissolved in water that had been acidified with acetic acid ( $\mathrm{pH} 4)$. All solvents employed were double-distilled or HPLC grade. All solvents and reagents were obtained from Sigma-Aldrich (Milan, Italy). Sodium $\left[1-{ }^{13} \mathrm{C}\right]$ acetate (isotopic purity 99 atom $\%{ }^{13} \mathrm{C}$ ) was obtained from the Euriso-Top Co. (Saint Aubin, France).

All microbial stains used in this study were obtained from the culture collection of the Dipartimento di S.A.V.A., Università del Molise. Cells of the yeast $R$. kratochvilovae LS11, originally isolated from an olive tree, were maintained viable in $20 \%$ glycerol at $-80{ }^{\circ} \mathrm{C}$. Cultures of $P$. expansum FS-7 were preserved on potato dextrose agar (PDA, $200 \mathrm{~g}$ of potatoes, $20 \mathrm{~g}$ of $\mathrm{D}$-glucose, and $20 \mathrm{~g}$ of agar per liter of distilled water) on slant tubes at $4{ }^{\circ} \mathrm{C}$.

Growth of $R$. kratochvilovae LS11 in the Presence of Unlabeled Patulin. For the analysis of patulin metabolization by $R$. kratochvilovae LS11, cells of the yeast were scraped from a Petri dish, added to $50 \mathrm{~mL}$ of Lilly-Barnett medium ( $\mathrm{LiBa}, 10.0 \mathrm{~g}$ of D-glucose, $2.0 \mathrm{~g}$ of L-asparagine, $1.0 \mathrm{~g}$ of $\mathrm{KH}_{2} \mathrm{PO}_{4}, 0.5 \mathrm{~g}$ of $\mathrm{MgSO}_{4} \cdot 7 \mathrm{H}_{2} \mathrm{O}, 0.01 \mathrm{mg}$ of $\mathrm{FeSO}_{4} \cdot 7 \mathrm{H}_{2} \mathrm{O}, 8.7 \mathrm{mg}$ of $\mathrm{ZnSO}_{4} \cdot 7 \mathrm{H}_{2} \mathrm{O}, 3.0 \mathrm{mg}$ of $\mathrm{MnSO}_{4} \cdot \mathrm{H}_{2} \mathrm{O}, 0.1 \mathrm{mg}$ of biotin, and $0.1 \mathrm{mg}$ of thiamine per liter of medium), ${ }^{26}$ and incubated at $23{ }^{\circ} \mathrm{C}$ on a rotary shaker at $150 \mathrm{rpm}$ for $24-36 \mathrm{~h}$. The culture was centrifuged for $20 \mathrm{~min}$ at $6000 \mathrm{rpm}$, the cell concentrations were adjusted to $1.0 \times 10^{5} \mathrm{CFU} / \mathrm{mL}$, corresponding to values of 0.01 optical density (OD) at $595 \mathrm{~nm}$, and the cells were transferred to three flasks, each containing $50 \mathrm{~mL}$ of $\mathrm{LiBa}$ supplemented with $150 \mu \mathrm{g} / \mathrm{mL}$ patulin. Three flasks each containing $50 \mathrm{~mL}$ of LiBa with $150 \mu \mathrm{g} / \mathrm{mL}$ patulin, and not inoculated with the yeast, were used as the control. All of the flasks were incubated on a rotary shaker at $150 \mathrm{rpm}$ and at $23^{\circ} \mathrm{C}$ for $72 \mathrm{~h}$. At 0 , 24,48 , and $72 \mathrm{~h}$, samples of $200 \mu \mathrm{L}$ were withdrawn from each flask for subsequent HPLC analyses of crude samples. The same experiments were also carried out in macerated browning apple tissue, supplemented with patulin, and inoculated with $R$. kratochvilovae LS11 as previously described. $^{21}$ The only difference from the previously reported biodegradation procedure ${ }^{21}$ was the volume of liquid used and the application of gentle shaking in the present experiments.

For NMR analysis of the major biodegradation product of patulin by R. kratochvilovae LS11, yeast cells were grown as described above, but after centrifugation they were transferred to a single flask containing $50 \mathrm{~mL}$ of $\mathrm{LiBa}$ with $250 \mu \mathrm{g} / \mathrm{mL}$ patulin. During the course of the incubation, the decrease in intensity of the spot corresponding to patulin and the increased intensity of two spots with $R_{f} 0.46$ and $R_{f} 0.38$, which appeared during incubation, were monitored by TLC. Forty microliter aliquots of culture filtrate, which had previously been extracted with ethyl acetate and concentrated, ${ }^{21,25}$ were applied on $0.25 \mathrm{~mm}$ thick plates (Merck Kiesegel $60 \mathrm{~F}_{254}$, Darmstadt, Germany), and chromatography was performed by using toluene-ethyl acetate-formic acid 5:4:1 $(\mathrm{v} / \mathrm{v} / \mathrm{v})$ as the solvent system. TLC results were first observed under UV light and then visualized by spraying with a $0.5 \%$ solution of 3-methyl-2benzothiazolinone hydrazone (Sigma-Aldrich, Milan, Italy) (w/v) and heating at $120^{\circ} \mathrm{C}$ for $15 \mathrm{~min}$. The biodegradation reaction was stopped after $96 \mathrm{~h}$, at which time the patulin spot and the one having $R_{f} 0.38$ could no longer be detected. The culture was centrifuged, cells were discarded, and the supernatant was lyophilized and then dissolved in acidified water $(\mathrm{pH} 4)$ prior to purification of the major biodegradation product.

HPLC Analyses of Patulin Metabolization by R. kratochvilovae LS11. HPLC analyses were performed as previously described ${ }^{27}$ with slight modifications. The HPLC apparatus was a Dionex (Sunnyvale, CA) analytical system consisting of a P680 solvent delivery system and a $20 \mu \mathrm{L}$ injector loop (Rheodyne, Cotati). The UVD170 detector (Dionex, Sunnyvale) set at $276 \mathrm{~nm}$ was connected to a data integration system (Dionex Chromeleon Version 6.6). The column used 
was a $250 \mathrm{~mm} \times 4.6 \mathrm{~mm}$ i.d., $5 \mu \mathrm{m}$, Agilent Zorbax C18 (Agilent technologies Italia s.p.a, Milan, Italy). The mobile phase was acidified water (with $1 \%$ acetic acid v/v) and methanol 95:5 (v/v) with a flow rate of $1 \mathrm{~mL} / \mathrm{min}$ and a total run of $18 \mathrm{~min}$. Standard serial solutions of patulin in acidified water were injected, and peak areas were determined to generate a standard curve for quantitative analyses. Quantitation of the major metabolite of patulin metabolization was also carried out as described for patulin, following purification and characterization as desoxypatulinic acid. The quantity of desoxypatulinic acid was determined by using a calibration curve with injected amounts, ranging from 0.02 to $0.4 \mu \mathrm{g}$. The linear fit was: $y=63.145 x-0.0521$ [Pearson's coefficient $\left.\left(R^{2}\right)=1\right]$. The limit of quantitation (LOQ) was $20 \mathrm{ng}(1 \mu \mathrm{g} /$ $\mathrm{mL}$ ), and the limit of detection (LOD) was $6.7 \mathrm{ng}(0.333 \mu \mathrm{g} / \mathrm{mL})$, with signal/noise $(\mathrm{S} / \mathrm{N})$ ratios of 9 and 3 , respectively. The experiments were performed three times, and each experiment consisted of three replicates. Data from the experiments were pooled, because they were similar in the three repetitions, and expressed as $\mu \mathrm{g} / \mathrm{mL}$ of patulin or desoxypatulinic acid \pm standard deviation.

Characterization of the Major Biodegradation Product of Patulin. Purification of the patulin degradation product was carried out using an HPLC apparatus series 200 Perkin-Elmer, equipped with a binary pump and a UV/vis 785 A detector set at $276 \mathrm{~nm}$. The column used was a $250 \times 4.6 \mathrm{~mm}$ i.d., $5 \mu$, Phenomenex Luna $\mathrm{C}_{18} 100 \mathrm{~A}$ (Torrance, CA). The mobile phase and flow were the same as for HPLC analyses. Twenty aliquots of $100 \mu \mathrm{L}$ were injected with an autosampler (Perkin-Elmer, USA), and fractions of $500 \mu \mathrm{L}$ each from the peak with retention time of $15.2 \mathrm{~min}$ were collected in the dark. Twenty fractions were pooled, and the solvent was evaporated under a $\mathrm{N}_{2}$ stream in a preweighed glass vial. After being dried, the weight of the purified sample was determined to $2.20 \mathrm{mg}$, and it was stored at $-20^{\circ} \mathrm{C}$.

Prior to NMR analysis, both this sample and a sample of patulin were dissolved in $\mathrm{D}_{2} \mathrm{O}$ with $0.17 \mathrm{M}$ deuterated acetic acid with $\mathrm{pH}$ adjusted to 4.0 by the addition of potassium carbonate. NMR spectra were performed at $300 \mathrm{~K}$ on an AVANCE AQS600 spectrometer (Bruker Biospin $\mathrm{GmbH}$ Rheinstetten, Karlsruhe, Germany) operating at the proton frequency of $600.13 \mathrm{MHz}$. The ${ }^{1} \mathrm{H}$ spectra were referred to the residual ${ }^{1} \mathrm{H}$ signal of $\mathrm{CHD}_{2} \mathrm{COOD}$ set at $2.08 \mathrm{ppm} .{ }^{13} \mathrm{C}$ spectra were referred to the ${ }^{13} \mathrm{C}$ methyl carbon of residual $\mathrm{CHD}_{2} \mathrm{COOD}$ set at $21.4 \mathrm{ppm}$.

2D NMR experiments, that is, ${ }^{1} \mathrm{H}-{ }^{1} \mathrm{H}$ COSY, ${ }^{1} \mathrm{H}-{ }^{13} \mathrm{C}$ HSQC, and ${ }^{1} \mathrm{H}-{ }^{13} \mathrm{C} \mathrm{HMBC}$, were performed using the same experimental conditions as previously reported by Mannina et al.; ${ }^{28}$ the delay for the evolution of long-range couplings in ${ }^{1} \mathrm{H}-{ }^{13} \mathrm{C} \mathrm{HMBC}$ experiments was $80 \mathrm{~ms}$.

Mass spectrum was recorded by $\mathrm{GC}-\mathrm{MS}$ with a VG-Autospec instrument. Calculated mass for $\mathrm{C}_{7} \mathrm{H}_{8} \mathrm{O}_{4}[\mathrm{M}]^{+}$was 156.0423 , while the one we found experimentally was 156.0415 .

Isotope Incorporation Studies. Labeled patulin was produced as follows: P. expansum strain FS-7 was grown at $25^{\circ} \mathrm{C}$, at $150 \mathrm{rpm}$, in four Erlenmeyer flasks $(500 \mathrm{~mL})$ each containing $300 \mathrm{~mL}$ of potato dextrose broth (PDB) medium (200 g of potatoes and $20 \mathrm{~g}$ of D-glucose per liter of distilled water), diluted with $\mathrm{H}_{2} \mathrm{O}$ to a final ratio of 1:10. Each flask was inoculated with fresh conidia to a final concentration of $4 \times 10^{6}$ conidia/mL. After 4 days of incubation (the time interval that was identified as the optimum one, following a time-course study on the in vitro formation of patulin), the mycelia from the four flasks were transferred into the same number of new Erlenmeyer flasks $(500 \mathrm{~mL})$, each containing $300 \mathrm{~mL}$ of PDB medium, diluted as above. A filtersterilized (by using $0.22 \mu \mathrm{m}$ filters) aqueous solution of sodium $\left[1-{ }^{13} \mathrm{C}\right]$ acetate was added at a final concentration of $300 \mu \mathrm{g} / \mathrm{mL}$. Three days after addition of the labeled precursor, the culture medium and mycelia were separated by filtration. The broth was saturated with $\mathrm{NaCl}$ and extracted three times with ethyl acetate. The organic extract was washed three times with $\mathrm{H}_{2} \mathrm{O}$, dried over anhydrous $\mathrm{Na}_{2} \mathrm{SO}_{4}$, and the solvent was evaporated under reduced pressure. The residue was purified by column chromatography on silica gel (Merck, Darmstadt, Germany), by using toluene/ethyl acetate/formic acid 5:4:1 (v/v/v) as the solvent system, to afford $55 \mathrm{mg}$ of labeled patulin.

A suspension of fresh cells of $R$. kratochvilovae LS11 $\left(1.0 \times 10^{5} \mathrm{CFU} /\right.$ $\mathrm{mL}$ ) was added to an Erlenmeyer flask $(500 \mathrm{~mL})$ containing $200 \mathrm{~mL}$ of Lilly-Barnett medium and $150 \mu \mathrm{g} / \mathrm{mL}$ of labeled patulin. The yeast was incubated for 4 days at $23{ }^{\circ} \mathrm{C}$, at $150 \mathrm{rpm}$. At this time point, the culture medium and the yeast cells were separated by centrifugation for $20 \mathrm{~min}$ at $6000 \mathrm{rpm}$. The medium was acidified to $\mathrm{pH} 2$ with an aqueous solution of $\mathrm{HCl} 2 \mathrm{M}$, saturated with $\mathrm{NaCl}$, and extracted three times with ethyl acetate. The ethyl acetate extract was washed three times with $\mathrm{H}_{2} \mathrm{O}$, dried over anhydrous $\mathrm{Na}_{2} \mathrm{SO}_{4}$, and the solvent was evaporated under reduced pressure. Purification of labeled desoxypatulinic acid was carried out as described for labeled patulin, to afford $26 \mathrm{mg}$ of this pure compound. The isotopic composition of patulin and desoxypatulinic acid was calculated by GC-HREIMS on VG-Autospec spectrometer following correction for natural abundance levels, which were determined experimentally using authentic and unlabeled standard compounds.

Effect of Patulin and Desoxypatulinic Acid on Cultured Human Lymphocytes. Peripheral lymphocytes were withdrawn from two healthy nonsmoking males belonging to AVIS (Italian Association of Voluntary Blood donors) who were less than 40 years old. Immediately after withdrawal, lymphocytes were separated from whole blood using a density gradient (Histopaque 1077 Sigma-Aldrich), and cultured at a concentration of $2 \times 10^{6}$ cells $/ \mathrm{mL}$ in $5 \mathrm{~mL}$ (i.e., $4 \times 10^{5}$ cells $/ \mathrm{mL}$ ) of RPMI 1640 medium (Sigma-Aldrich) supplemented with 15\% fetal calf serum, $1 \%$ phytohemagglutinin, $1 \%$ penicillin-streptomycin solution (v/v), and $1 \mathrm{mM}$ L-glutamine (Sigma-Aldrich). The cultures were incubated at $37{ }^{\circ} \mathrm{C}$ in a humid atmosphere in the presence of $5 \% \mathrm{CO}_{2}$ (v/v). After $48 \mathrm{~h}$, lymphocyte cultures were treated with patulin or with desoxypatulinic acid (the purified major product of patulin metabolization by the yeast, which had been identified by NMR analyses). Both desoxypatulinic acid and patulin were individually dissolved in sterile double-distilled water and added to lymphocyte cultures to obtain final concentrations of $0.1,0.5,1,5,10,50$, and $100 \mu \mathrm{M}$. Cell concentrations were measured as a function of time by trypan blue-exclusion test. Cell aliquots withdrawn from each culture at 3 and $24 \mathrm{~h}$ from the beginning of the experiment were mixed with an equal volume of trypan blue solution (diluted at $0.8 \mathrm{mM}$ in PBS) for $2 \mathrm{~min}$ at room temperature, and the cells that stained positive were counted under a light microscope. Living cells with membrane integrity do not take up trypan blue, while dead cells with damaged membranes stain blue due to the uptake of trypan blue. The percentage of live lymphocytes was determined as the ratio of the number of nontrypan blue (negative) cells (i.e., living cells) to the total number of cells, that is, the sum of trypan blue (positive) cells (i.e., dead cells) and living cells. ${ }^{29,30}$ Results were expressed as the percentage of viable cells in treated cultures, which was compared to that of untreated control cultures. Each treatment was performed in duplicate with separate cultures of cells from two donors (i.e., four cultures were setup for each treatment). The experiment was performed twice. Only the results from one experiment are reported because the outcome was similar in both cases.

Fate of Patulin and Desoxypatulinic Acid in the Presence of Glutathione in Vitro. These experiments were performed following the method described by Pfeiffer et al. ${ }^{31}$ with slight modifications. Patulin or desoxypatulinic acid $(10 \mathrm{mM})$ was incubated with a 5-fold molar excess of GSH ( $50 \mathrm{mM})$ in $67 \mathrm{mM}$ potassium phosphate buffer, $\mathrm{pH} 7$, at $37^{\circ} \mathrm{C}$ for $24 \mathrm{~h}$. Controls were patulin and desoxypatulinic acid incubated in buffer under the same conditions as above in the absence of GSH. Aliquots of $100 \mu \mathrm{L}$ were taken from the incubation mixtures at 0 , $1 / 12$ (i.e., $5 \mathrm{~min}$ ), 1,6 , and $24 \mathrm{~h}$, acidified with $10 \mu \mathrm{L}$ of formic acid, and analyzed for the presence of patulin and desoxypatulinic acid by HPLC. Analyses were performed using a Shimadzu LC10 HPLC instrument 
(Shimadzu, Kyoto, Japan) equipped with a photodiode array detector. Separation was carried out using the same column and the same initial mobile phase [acidified water (with $1 \%$ acetic acid v/v) and methanol 95:5 (v/v) with a flow rate of $1 \mathrm{~mL} / \mathrm{min}$ ] as those used for patulin and desoxypatulinic acid analysis in the biodegradation experiments, with the following linear gradient: 5\% methanol for $20 \mathrm{~min}, 5-100 \%$ methanol in $40 \mathrm{~min}$.

Statistical Analysis. Data from all of the experiments reported in this study were analyzed with the SPSS program (SPSS Inc., Chicago, IL, release 15 for Windows). Data obtained from the three experiments of patulin metabolization by R. kratochvilovae LS11 were similar, so they were pooled prior to statistical analysis. Likewise, the results from the three experiments of the in vitro binding of patulin and desoxypatulinic acid to glutathione were pooled because the data were similar. Results from the experiments of patulin metabolization were expressed as $\mu \mathrm{g} /$ $\mathrm{mL}$ of patulin or desoxypatulinic acid \pm standard deviation $(n=9)$. Those assessing the fate of patulin and desoxypatulinic acid in the presence of glutathione were expressed as millimolar concentrations of the two compounds \pm standard deviation $(n=9)$. The results were analyzed by Student's $t$ test $(P<0.001)$. Results of the effect of patulin and desoxypatulinic acid on cultured human lymphocytes were expressed as percentage of viable cells \pm standard deviation in treated cultures $(n=8)$. Percentages were compared to those of the untreated control by Student's $t$ test (at $P<0.05$ ).

\section{RESULTS AND DISCUSSION}

Analytical HPLC chromatograms demonstrating the typical fate of patulin after $0,24,48$, and $72 \mathrm{~h}$ of in vitro incubation with the yeast $R$. kratochvilovae LS11 are presented in Figure 1A-D. In the presence of the yeast, the concentration of patulin progressively decreased, and only $3.7 \pm 1.2 \mu \mathrm{g} / \mathrm{mL}$ of the mycotoxin could be detected $72 \mathrm{~h}$ after the beginning of the experiment. Conversely, approximately the same concentration of patulin added to the noninoculated growth medium (control) at the beginning of the experiment $(150 \mu \mathrm{g} / \mathrm{mL})$ was recorded at the same time point. Interestingly, in the presence of the yeast, a peak with Rt $14.70 \mathrm{~min}$ appeared over the first time interval $(0-24 \mathrm{~h})$ (Figure 1B) and progressively increased with time paralleling the decrease of patulin (Figure 1C,D). This new peak corresponds to desoxypatulinic acid, as shown by NMR (Figure 2A), and to the spot in thin layer chromatography analyses with the $R_{f} 0.46$ (data not shown). ${ }^{21}$ The concentration of desoxypatulinic acid progressively increased and reached the value of $87.0 \pm 11.7 \mu \mathrm{g} / \mathrm{mL}$ at $72 \mathrm{~h}$. Similar results were obtained when patulin was incubated with strain LS11 in browning and macerated apple tissue (data not shown). ${ }^{21}$ The quantitative analyses of patulin and desoxypatulinic acid show that the yeast metabolizes patulin almost completely within $72 \mathrm{~h}$ and confirm its ability to resist high patulin concentrations. ${ }^{21}$ Because patulin is a broad-spectrum toxin and antifungal agent, it is potentially lethal also to $R$. kratochvilovae LS11, which may convert it to desoxypatulinic acid to protect itself against the toxin. Scott et al. reported that $46 \mu \mathrm{g} / \mathrm{mL}$ of this compound was not toxic to a number of bacteria and yeasts, whose growth was completely inhibited by patulin under the same conditions. ${ }^{32}$ In fruit wounds, the basidiomycetous yeast $R$ kratochvilovae LS11 can utilize its capacity to convert patulin to desoxypatulinic acid to protect itself and the fruit from one of the weapons of the green mold fungus.

Desoxypatulinic acid was identified as the major compound deriving from patulin biodegradation in vitro by LS11 following purification and subsequent NMR analysis. The chromatographic conditions for HPLC quantitative analyses of patulin
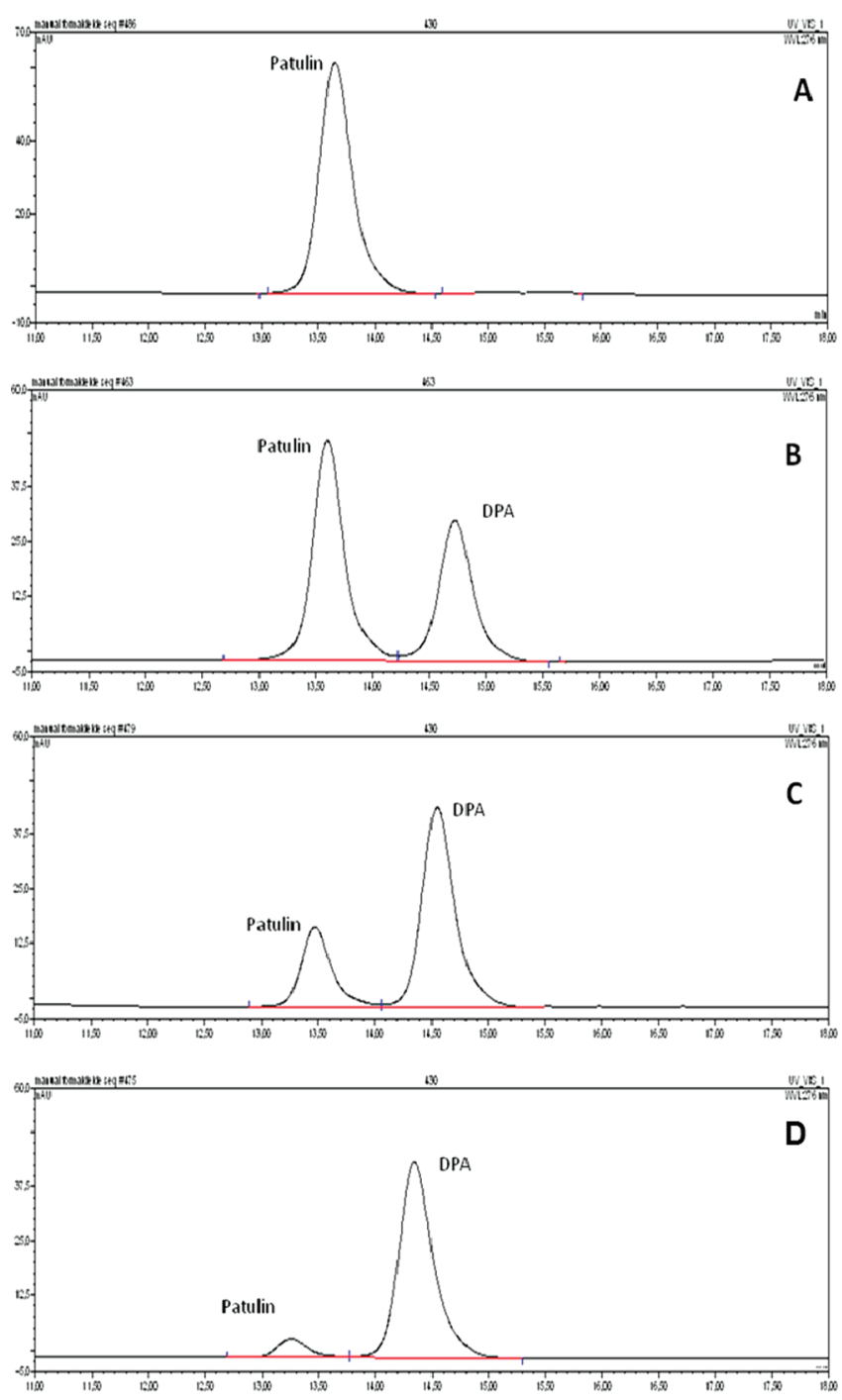

Figure 1. Time-course HPLC chromatograms of in vitro patulin degradation and production of desoxypatulinic acid (DPA) by the biocontrol yeast Rhodosporidium kratochvilovae strain LS11 following incubation for 0 (A), 24 (B), 48 (C), and $72 \mathrm{~h}(\mathrm{D})$.

were similar to those used for the purification of desoxypatulinic acid and subsequent NMR analysis. A yield of $2.20 \mathrm{mg}$ of desoxypatulinic acid was obtained and used for NMR analysis and structural characterization.

The assignment of ${ }^{1} \mathrm{H}$ and ${ }^{13} \mathrm{C}$ NMR spectra of patulin in $\mathrm{D}_{2} \mathrm{O}$ /acetic acid is reported in Table 1 . The high-resolution mass spectrum of the major biodegradation product indicated a molecular formula $\mathrm{C}_{7} \mathrm{H}_{8} \mathrm{O}_{4}$. To determine its molecular structure, a complete NMR study, including $1 \mathrm{D}$ and $2 \mathrm{D}$ experiments, ${ }^{1} \mathrm{H}-{ }^{1} \mathrm{H}$ COSY, ${ }^{1} \mathrm{H}-{ }^{13} \mathrm{C} \mathrm{HSQC}$, and ${ }^{1} \mathrm{H}-{ }^{13} \mathrm{C} \mathrm{HMBC}$ (Figure $2 \mathrm{C}$ ), was performed. The ${ }^{1} \mathrm{H}$ spectrum of this stable metabolite shows the presence of three $\mathrm{CH}_{2}$ groups labeled as 2, 3, and 7 and one $\mathrm{CH}$ group labeled as 6. The $\mathrm{CH}_{2}-2$ at $4.61 \mathrm{ppm}$ and the $\mathrm{CH}_{2}-3$ at 2.72 ppm correlate in COSY experiment and therefore belong to a $\mathrm{CH}_{2}-\mathrm{CH}_{2}$ fragment, while $\mathrm{CH}_{2}-7$ is a doublet with a very small coupling constant, indicating the absence of the vicinal $\mathrm{CH}_{x}$ groups.

The ${ }^{1} \mathrm{H} /{ }^{13} \mathrm{C}$ chemical shifts of $\mathrm{CH}_{2}-2$ group in this metabolite are similar to chemical shifts of $\mathrm{CH}_{2}-6$ of patulin (Figure 2A,B), suggesting a structural similarity $\left(\mathrm{O}-\mathrm{CH}_{2}\right)$, but the multiplicity 

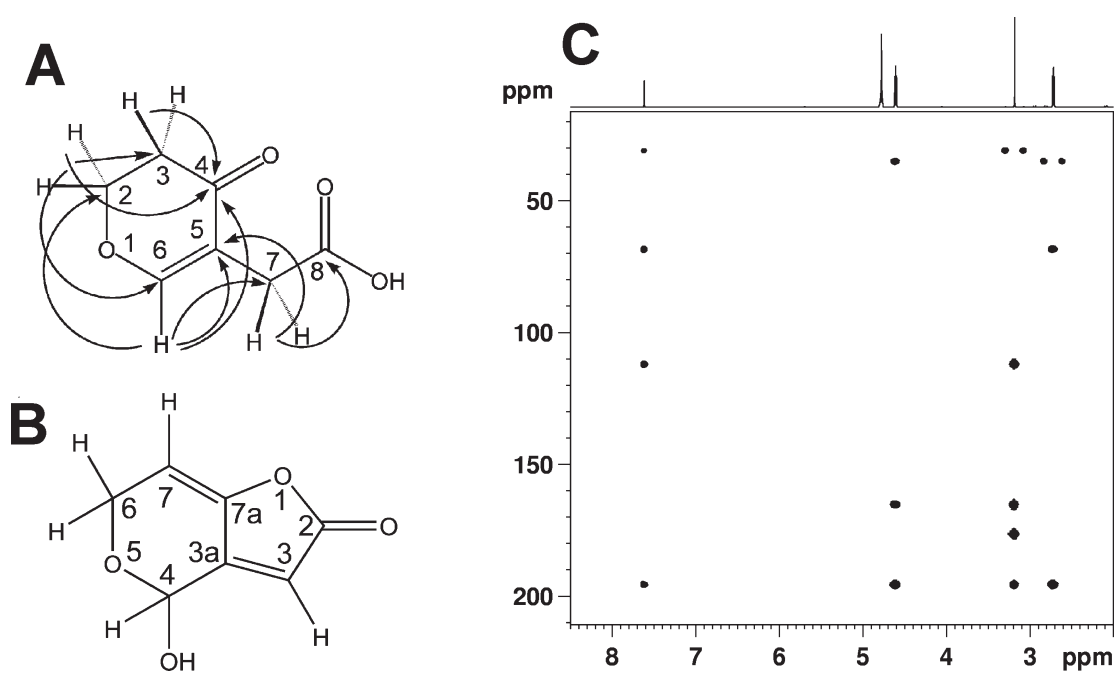

Figure 2. Structures of (A) desoxypatulinic acid (arrows indicate key long-range correlations in $\mathrm{HMBC}$ spectrum) and (B) patulin. $(\mathrm{C}){ }^{1} \mathrm{H}-{ }^{13} \mathrm{C}$ $\mathrm{HMBC}$ spectrum of desoxypatulinic acid in $\mathrm{D}_{2} \mathrm{O} /$ acetic acid at $27^{\circ} \mathrm{C}$.

Table 1. ${ }^{1} \mathrm{H}$ and ${ }^{13} \mathrm{C}$ Assignments of Patulin and Desoxypatulinic Acid in $\mathrm{D}_{2} \mathrm{O} /$ Acetic Acid

\begin{tabular}{|c|c|c|c|c|c|c|c|}
\hline \multicolumn{4}{|c|}{ patulin } & \multicolumn{4}{|c|}{ desoxypatulinic acid } \\
\hline group & ${ }^{1} \mathrm{H}(\mathrm{ppm})$ & multiplicity: $J,(\mathrm{~Hz})$ & ${ }^{13} \mathrm{C}(\mathrm{ppm})$ & group & ${ }^{1} \mathrm{H}(\mathrm{ppm})$ & multiplicity: $J,(\mathrm{~Hz})$ & ${ }^{13} \mathrm{C}(\mathrm{ppm})$ \\
\hline $\mathrm{CH}(3,7)$ & $6.20-6.22$ & $\mathrm{~m}$ & 110.2 & $\mathrm{CH}(6)$ & 7.62 & $\mathrm{t}:<0.7$ & 164.7 \\
\hline $\mathrm{CH}(4)$ & 6.14 & s & 88.3 & $\mathrm{CH}_{2}(2)$ & 4.61 & $\mathrm{t}: 7.1$ & 67.9 \\
\hline \multirow[t]{2}{*}{$\mathrm{CH}_{2}\left(6,6^{\prime}\right)$} & 4.70 & $\mathrm{dd}: 17.5,3.0$ & 59.5 & $\mathrm{CH}_{2}$ (3) & 2.72 & $\mathrm{t}: 7.1$ & 34.6 \\
\hline & 4.53 & dd: $17.5,3.8$ & & & & & \\
\hline $\mathrm{C}=\mathrm{O}(2)$ & & & 172.2 & $\mathrm{CH}_{2}(7)$ & 3.18 & $\mathrm{~d}:<0.7$ & 30.5 \\
\hline$C(7 a)$ & & & 145.9 & $\mathrm{C}=\mathrm{O}(4)$ & & & 195.6 \\
\hline \multirow[t]{2}{*}{$C(3 a)$} & & & 151.3 & $\mathrm{C}=\mathrm{C}(5)$ & & & 111.8 \\
\hline & & & & $\mathrm{COOH}(8)$ & & & 176.5 \\
\hline
\end{tabular}

of ${ }^{1} \mathrm{H}$ signals is different. Geminal protons of the patulin $\mathrm{CH}_{2}-6$ group are not chemically equivalent (Table 1), being close to the asymmetric C-4 carbon atom, whereas the protons of the $\mathrm{CH}_{2}-2$ group of the biodegradation product of patulin are equivalent, indicating the transformation of chiral $\mathrm{CH}(\mathrm{OH})-4$ group into a nonchiral one.

The carbon skeleton of the patulin biodegradation product was unequivocally assigned using long-range ${ }^{1} \mathrm{H}-{ }^{13} \mathrm{C}$ correlations (Figure 2C). Long-range contacts between protons of $\mathrm{CH}_{2}-2$ and carbon $\mathrm{C}-6$ and between proton $\mathrm{CH}-6$ and carbon $\mathrm{C}-2$ in the HMBC spectrum, together with diagnostic chemical shifts, suggested that the $\mathrm{CH}(\mathrm{OH})-4$ group of patulin was transformed into a $\mathrm{CH}=(6)$ group in this metabolite. The signals of the $\mathrm{COOH}(8)$ and $\mathrm{C}=\mathrm{O}(4)$ groups in the ${ }^{13} \mathrm{C} N M R$ spectrum indicate the opening of the lactone ring. These results and the ${ }^{1} \mathrm{H}-{ }^{13} \mathrm{C}$ long-range correlations of protons with three quaternary carbons in the HMBC experiment (Figure 2A) enabled us to identify the metabolite as desoxypatulinic acid. The corresponding NMR assignments for desoxypatulinic acid are presented in Table 1. This compound had previously been isolated by Scott et al. from Penicillium patulum. ${ }^{32}$ The spectroscopic data of the metabolite resulting from patulin biodegradation agreed with those published in the literature for desoxypatulinic acid. ${ }^{32}$ The present study is the first to report the production of desoxypatulinic acid by a microorganism other than Penicillium sp., as a biodegradation product of patulin.

Isotope incorporation experiments show that biodegradation of ${ }^{13}$ C-labeled patulin by $R$. kratochvilovae LS11 led to the emergence of ${ }^{13} \mathrm{C}$-labeled desoxypatulinic acid, the major biodegradation product, with a similar distribution of label as in the original ${ }^{13} \mathrm{C}$-labeled patulin. The specific ${ }^{13} \mathrm{C}$ incorporation into patulin and desoxypatulinic acid was analyzed by HREIMS. This analytical method involves obtaining the spectra of the labeled compound and the unlabeled analogue under conditions as identical as possible. The isotopic composition of the labeled compound is determined by subtracting the relative abundance ratios of the labeled and unlabeled species in the ratio found for the unlabeled compound.

GC-MS analysis of patulin revealed that up to three ${ }^{13} \mathrm{C}$ labels were incorporated in $0.3 \%$ of the molecules, following administration of sodium $\left[1-{ }^{13} \mathrm{C}\right]$ acetate to P. expansum FS-7, whereas $14.7 \%$ and $1.5 \%$ of the molecules carried one and two ${ }^{13} \mathrm{C}$ atom(s), respectively. Isotope incorporation was also detected in desoxypatulinic acid, following incubation of $\mathrm{R} . \mathrm{kra}$ tochvilovae LS11 with ${ }^{13} \mathrm{C}$-labeled patulin. Most importantly, a similar percentage of the molecules of desoxypatulinic acid (14.4\%) carried one ${ }^{13} \mathrm{C}$ label. However, no incorporation of more than one ${ }^{13} \mathrm{C}$ atom was detected in desoxypatulinic acid 
Table 2. Effect of Different Concentrations of Patulin (PAT) and Desoxypatulinic Acid (DPA) on the Viability of Cultured Human Lymphocytes

\begin{tabular}{|c|c|c|}
\hline \multirow[b]{2}{*}{ treatment } & \multicolumn{2}{|c|}{ duration of treatment } \\
\hline & viable cells (\%), $3 \mathrm{~h}$ & viable cells (\%), $24 \mathrm{~h}$ \\
\hline \multicolumn{3}{|c|}{$\operatorname{PAT}(\mu \mathrm{M})$} \\
\hline 0.1 & $94.00 \pm 1.41$ & $92.50 \pm 2.12$ \\
\hline 0.5 & $92.00 \pm 4.24$ & $89.50 \pm 3.54$ \\
\hline 1 & $89.00 \pm 14.14$ & $68.00 \pm 7.07^{a}$ \\
\hline 5 & $78.50 \pm 12.02$ & $46.00 \pm 9.90^{a}$ \\
\hline 10 & $78.00 \pm 1.41^{a}$ & $38.00 \pm 14.14^{a}$ \\
\hline 50 & $77.00 \pm 4.24^{a}$ & $30.00 \pm 11.10^{a}$ \\
\hline 100 & $66.50 \pm 9.21^{a}$ & $25.00 \pm 5.66^{a}$ \\
\hline \multicolumn{3}{|c|}{$\mathrm{DPA}(\mu \mathrm{M})$} \\
\hline 0.1 & $95.50 \pm 0.71$ & $93.50 \pm 2.12$ \\
\hline 0.5 & $94.50 \pm 0.71$ & $92.00 \pm 1.41$ \\
\hline 1 & $93.00 \pm 1.41$ & $90.00 \pm 1.41$ \\
\hline 5 & $91.00 \pm 7.07$ & $88.00 \pm 2.83$ \\
\hline 10 & $90.00 \pm 5.56$ & $87.50 \pm 4.95$ \\
\hline 50 & $89.00 \pm 8.49$ & $74.50 \pm 4.95^{a}$ \\
\hline 100 & $87.50 \pm 7.78$ & $45.00 \pm 4.24^{a}$ \\
\hline control & $95.50 \pm 2.12$ & $96.00 \pm 1.41$ \\
\hline
\end{tabular}

${ }^{a}$ Significantly different from control according to Student's test $(P<0.05)$.

because of the low relative intensities of the isotopic peaks in the HREIMS spectrum for the labeled and unlabeled compound. These results prove that desoxypatulinic acid derives from metabolization of patulin by the yeast.

Table 2 shows the percentage of viable human lymphocytes following incubation with $0.1-100 \mu \mathrm{M}$ of patulin or desoxypatulinic acid for 3 and $24 \mathrm{~h}$. The harvested cells were counted. The percentage of viable cells in control cultures was similar at both time points. Treatment with patulin caused a significant decrease in the number of viable cells in a time- and dose-dependent manner. The most rapid patulin-induced effect on lymphocyte viability was observed after $3 \mathrm{~h}$ of incubation with patulin at 10 $\mu \mathrm{M}$, when a decrease of viable cells slightly above $20 \%$ was recorded. The lowest patulin concentration that had a significant effect on the viability of lymphocytes was $1 \mu \mathrm{M}$, which caused a decrease of approximately $30 \%$ of viable cells after $24 \mathrm{~h}$. The most dramatic effect was recorded after $24 \mathrm{~h}$ of incubation and with the highest concentration of patulin, that is, $100 \mu \mathrm{M}$, which caused a decrease of $70 \%$ in lymphocyte viability. The observed cytotoxicity of patulin in the present study agrees with that observed by other authors on other cell lines. ${ }^{6,33}$ Conversely, desoxypatulinic acid, on the other hand, was not cytotoxic to lymphocytes following $3 \mathrm{~h}$ of incubation, for the whole range of concentrations used. Desoxypatulinic acid was slightly toxic only at the highest concentrations tested (50 and $100 \mu \mathrm{M}$ ) and over the longest period of incubation $(24 \mathrm{~h})$.

The mechanism of patulin toxicity is usually attributed to its reactivity to thiol groups, which are present in cysteine, glutathione, and in cellular enzymes that contain thiol groups in their active sites. Patulin thus destroys and inactivates these compounds and blocks the active sites of enzymes containing sulfhydryl groups. ${ }^{7,34}$ Within the patulin molecule, carbon 3, 4, or

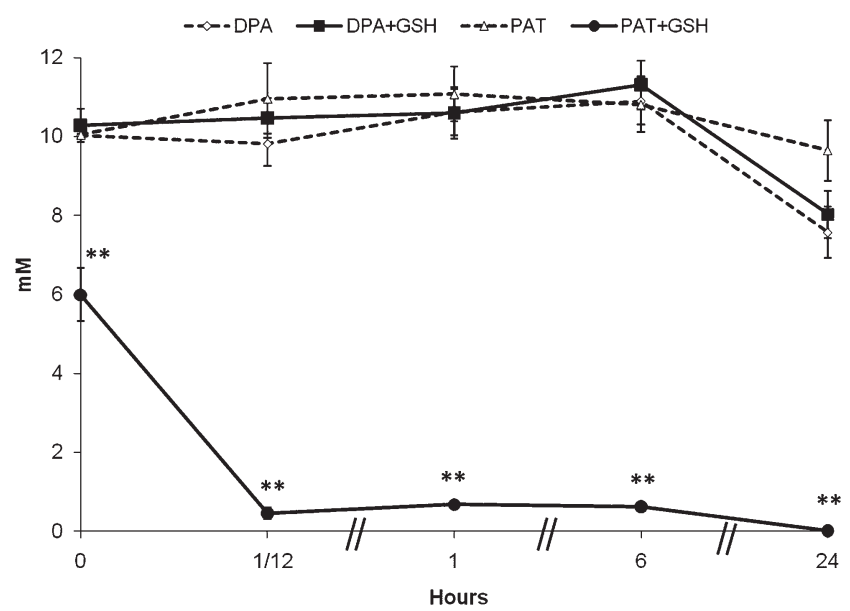

Figure 3. Time-course of the persistence of $10 \mathrm{mM}$ patulin (PAT) and $10 \mathrm{mM}$ desoxypatulinic acid (DPA), following incubation for $24 \mathrm{~h}$ at $37^{\circ} \mathrm{C}$ and $\mathrm{pH} 7$ in the presence of $50 \mathrm{mM}$ of the thiol-bearing tripeptide glutathione $(\mathrm{GSH})$. Values $(\mathrm{mM})$ are the means \pm standard deviation $\left(n=9\right.$, using three measurements in three experiments). Symbols $\left({ }^{* *}\right)$ indicate highly significant differences $(P<0.001)$ between the resulting PAT and DPA concentrations in the presence of GSH at the same time points, when analyzed by Student's $t$ test.

7 has been demonstrated to bind covalently to thiol groups. ${ }^{6,7}$ The biotransformation of patulin into desoxypatulinic acid by $R$. kratochvilovae LS11 leads to the loss of the hydroxyl group at C-4 of patulin, thus hindering the nucleophilic substitution at the corresponding carbon in the molecule of desoxypatulinic acid (C6). Desoxypatulinic acid could possibly undergo a Michaellike addition of thiol groups at C-6 because of the presence of an $\alpha, \beta$-unsaturated carbonyl system. However, reports show that similar $\alpha, \beta$-unsaturated ketones do not add thiol nucleophiles to this position, possibly because of deactivation by the ring oxygen. ${ }^{34}$

The proposed inability of desoxypatulinic acid to react with thiol groups is supported by the results reported in Figure 3, showing the fate of patulin and desoxypatulinic acid in the presence of glutathione at $37^{\circ} \mathrm{C}$ and $\mathrm{pH}$ 7. In these experiments, the mycotoxin reacted so rapidly with glutathione that even at time 0 the concentration of patulin in the presence of glutathione was lower than in the respective control (i.e., patulin in the absence of glutathione). After $5 \mathrm{~min}$ and until the end of the experiment, very low concentrations of patulin were present in the reaction buffer, whereas in the absence of glutathione the concentration of the mycotoxin remained unchanged at all time points. The concentration of desoxypatulinic acid, in contrast to that of patulin, remained almost unaffected over time in the presence of glutathione. A slight decrease of desoxypatulinic acid concentrations was only detected at $24 \mathrm{~h}$, both in the presence and in the absence of glutathione.

The absence of thiol-binding activity of desoxypatulinic acid could provide an explanation for the low toxicity of this compound. The low toxicity of desoxypatulinic acid could be due to the loss of the hemiacetal group ${ }^{35}$ and the hydrolysis of the lactone ring. The well-known instability of patulin in alkaline conditions, which leads to loss of biological activity, ${ }^{36}$ is a consequence of the opening of the lactone ring, suggesting that the lactone component of patulin is essential to its toxicity. Moreover, desoxypatulinic acid is more hydrophilic than patulin, and the increased polarity would facilitate its excretion from the body after ingestion. 
The ascomycetous yeast Saccharomyces cerevisiae is known to metabolize patulin to $E$-ascladiol under anaerobic conditions. This explains why patulin contamination in fermented drinks such as cider is usually lower than in juices and other nonfermented pome fruit-based products. ${ }^{12,22,23}$ E-Ascladiol has no hemiacetal group (which would probably account for its slightly lower toxicity as compared to patulin), but retains the integrity of the lactone ring in its molecular structure. It is in itself considered to be a mycotoxin, although with less acute toxicity than patulin. ${ }^{24}$ The biodegradation of patulin by $R$. kratochvilovae LS11 to desoxypatulinic acid has the additional advantage that it is an aerobic process. From a practical perspective, an aerobic degradation pathway is advantageous for the development of a large-scale apple juice detoxification process, because costly removal of oxygen becomes unnecessary.

The present study shows that a biocontrol yeast, $R$. kratochvilovae LS11, forms a novel degradation product, desoxypatulinic acid, from the mycotoxin patulin. Desoxypatulinic acid is much less toxic than patulin. This conversion by strain LS11 can therefore be considered to be a detoxification process. Future studies will include toxicity and genotoxicity tests of desoxypatulinic acid to cultured human cells, and the elucidation of the degradation pathway. The future identification of the enzymes involved in the degradation process will enable the development of tools for a more effective prevention and diagnosis of patulin contamination in pome fruit-derived products.

\section{ASSOCIATED CONTENT}

S Supporting Information. Figure 1: COSY of desoxypatulinic acid. Figure $2:{ }^{1} \mathrm{H}-{ }^{13} \mathrm{C}$ HSQC of desoxypatulinic acid. This material is available free of charge via the Internet at http:// pubs.acs.org.

\section{AUTHOR INFORMATION}

\section{Corresponding Author}

*Tel: +39(0)8744004698. Fax: +39(0)8744004652. E-mail: castoria@unimol.it.

\section{Present Addresses}

$\nabla$ Dipartimento di Scienze e Tecnologie Agro-Alimentari, Ambientali e Microbiologiche, Università degli Studi del Molise, Via F. De Sanctis snc, 86100 Campobasso, Italy.

${ }^{\circ}$ Dipartimento di Chimica e Tecnologie del Farmaco, Sapienza Università di Roma, 00185 Rome, Italy.

\section{Funding Sources}

This research was funded by the Italian Ministry of University and Scientific Research (MIUR): Project PRIN no. 2006072204 "Pilot study on innovative systems for the reduction of patulin contamination in pome fruits", and bilateral cooperation between Italy and Spain "Studio del pathway di biodegradazione della micotossina patulina operata da un lievito basidiomicete" no. IT088MB951. S.A.I.W. participated in this work thanks to the grant obtained by MIUR "Incentivazione alla mobilità di studiosi stranieri e italiani residenti all'estero” (DM 1.2.2005, no. 18).

\section{ACKNOWLEDGMENT}

We wish to thank A. Spina and V. Morena for their collaboration in carrying out the preliminary experiments of this work. We are also indebted to Dr. Alexander Idnurm (UMKC, MI) and
Dr. José Paulo Sampaio (UNL, Portugal) for taxonomic reclassification of strain LS11 as Rhodosporidium kratochvilovae, and to Dr. Alison Hill (University of Exeter, UK) and Dr. Rebecca Goss (UEA, UK) for their helpful suggestions.

\section{REFERENCES}

(1) Castoria, R.; Logrieco, A. Mycotoxins in fruits and major fruitderived products - an overview. In Microbial Biotechnology in Horticulture; Ward, O. P., Ray, R. C., Eds.; Science Publishers: New Hampshire, 2007; Vol. II, pp 305-344.

(2) Moake, M. M.; Padilla-Zakour, O. I.; Worobo, R. W. Comprehensive review of patulin control methods in foods. Compr. Rev. Food Sci. Food Saf. 2005, 1, 8-21.

(3) Bourdiol, D.; Escoula, L. Effect of patulin on microbicidal activity of mouse peritoneal macrophages. Food Chem. Toxicol. 1990, 28, 29-33.

(4) IARC. Patulin. Monograph No. 40 on the Evaluation of Carcinogenic Risk of Chemicals to Man; International Agency for Research on Cancer (IARC): Lyon, France, 1986; pp 83-98.

(5) Si-min, Z.; Li-ping, J.; Cheng-yan, G.; Jun, C.; Lai-fu, Z. Patulininduced genotoxicity and modulation of glutathione in HepG2 cells. Toxicon 2009, 53, 584-586.

(6) Mahfoud, R.; Maresca, M.; Garmy, N.; Fantini, J. The mycotoxin patulin alters the barrier function of the intestinal epithelium: Mechanism of action of the toxin and protective effects of glutathione. Toxicol. Appl. Pharmacol. 2002, 181, 209-218.

(7) Fliege, R.; Metzler, M. Electrophilic properties of patulin. N-Acetylcysteine and glutathione adducts. Chem. Res. Toxicol. 2000, 13, 373-381.

(8) FAO. Worldwide Regulations for Mycotoxins. A compendium. Food and Nutrition Paper No. 64, Food and Nutrition Division; FAO: Rome, Italy, 1997.

(9) European Commission (EC). Regulation (EC) No. 455/2004 amending Regulation (EC) No. 466/2001 as regards patulin. Off. J. Eur. Union L74, 11.

(10) FAO/WHO. Proposed draft code of practice for the prevention of patulin contamination in apple juice and apple juice ingredients in other beverages. Joint FAO/WHO Food Standards Programme reports, Codex Committee on Food Additives and Contaminants, 34th session; Rotterdam, The Netherlands, 2002; pp 1-8.

(11) Karlovsky, P. Biological detoxification of fungal toxins and its use in plant breeding, feed and food production. Nat. Toxins 1999, 7, 1-23.

(12) Moss, M. O.; Long, M. T. Fate of patulin in the presence of yeast Saccharomyces cerevisiae. Food Addit. Contam. 2002, 19, 387-399.

(13) Janisiewicz, W. J.; Korsten, L. Biological control of postharvest diseases of fruits. Annu. Rev. Phytopathol. 2002, 40, 411-441.

(14) Castoria, R.; Wright, S. A. I.; Droby, S. Biological control of mycotoxigenic fungi in fruits. In Mycotoxins in Fruits and Vegetables; Barkai-Golan, R., Paster, N., Eds.; Elsevier: San Diego, CA, 2008; pp 311-333.

(15) Castoria, R.; De Curtis, F.; Lima, G.; De Cicco, V. $\beta$-1,3glucanase activity of two saprophytic yeasts and possible mode of action involved as biocontrol agents against postharvest diseases. Postharvest Biol. Technol. 1997, 12, 293-300.

(16) Castoria, R.; De Curtis, F.; Lima, G.; Caputo, L.; Pacifico, S.; De Cicco, V. Aureobasidium pullulans (LS-30) an antagonist of postharvest pathogens of fruits: study on its modes of action. Postharvest Biol. Technol. 2001, 22, 7-17.

(17) Castoria, R.; Caputo, L.; De Curtis, F.; Lima, G.; De Cicco, V. Resistance to oxidative stress of postharvest biocontrol yeast: a possible new mechanism of action. Phytopathology 2003, 93, 564-572.

(18) Ippolito, A.; Nigro, F. Impact of preharvest application of biological control agents on postharvest diseases of fresh fruits and vegetables. Crop Prot. 2000, 19, 715-723.

(19) de Felice, D. V.; Solfrizzo, M.; De Curtis, F.; Lima, G.; Visconti, A.; Castoria, R. Strains of Aureobasidium pullulans can lower ochratoxin A contamination in wine grapes. Phytopathology 2008, $98,1261-1270$ 
(20) Lima, G.; De Curtis, F.; Castoria, R.; De Cicco, V. Integrated control of apple postharvest pathogens and survival of biocontrol yeasts in semi-commercial conditions. Eur. J. Plant Pathol. 2003, 109, 341-349.

(21) Castoria, R.; Morena, V.; Caputo, L.; Panfili, G.; De Curtis, F.; De Cicco, V. Effect of the biocontrol yeast Rhodotorula glutinis strain LS11 on patulin accumulation in stored apples. Phytopathology 2005, 95, 1271-1278.

(22) Harwig, J.; Scott, P. M.; Kennedy, B. P. C.; Chen, Y. K. Disappearance of patulin from apple juice fermented by Saccharomyces spp. Can. Inst. Food Sci. Technol. J. 1973, 6, 45-46.

(23) Stinson, E. E.; Osman, S. F.; Huhtanen, C. N.; Bills, D. D. Disappearance of patulin during alcoholic fermentation of apple juice. Appl. Environ. Microbiol. 1978, 36, 620-622.

(24) Suzuki, T.; Takeda, M.; Tanabe, H. A new mycotoxin produced by Aspergillus clavatus. Chem. Pharm. Bull. 1971, 19, 1786-1788.

(25) Cole, R. J., Cox, R. H., Eds. Toxic lactones. Handbook of Toxic Fungal Metabolites; Academic Press Inc.: New York, 1981; pp 510-526.

(26) Lilly, V. G.; Barnett, H. L. Physiology of the Fungi; McGraw-Hill: New York, 1951.

(27) MacDonald, S.; Long, M.; Gilbert, J. Liquid Chromatographic method for determination of patulin in clear and cloudy apple juices and apple puree: collaborative study. J. AOAC Int. 2000, 83, 1387-1394.

(28) Mannina, L.; Viel, S.; Duprè, S.; Pecci, L.; Fontana, M.; Pinnen, F.; Antonucci, A.; Segre, A. L. Structural elucidation of the oxidation product of aminoethylcysteine ketimine decarboxylated dimer by peroxynitrite. Tetrahedron 2004, 60, 4151-4157.

(29) Patterson, M. K., Jr. Measurement of growth and viability of cells in culture. Methods Enzymol. 1979, 58, 141-152.

(30) Uliasz, F.; Hewett, S. J. A microtiter trypan blue absorbance assay for the quantitative determination of excitotoxic neuronal injury in cell culture. J. Neurosci. Methods 2000, 100, 157-163.

(31) Pfeiffer, E.; Diwald, T. T.; Metzler, M. Patulin reduces glutathione level and enzyme activities in rat liver slices. Mol. Nutr. Food Res. 2005, 49, 329-336.

(32) Scott, P. M.; Kennedy, B.; Van Walbeek, W. Desoxypatulinic acid from a patulin-producing strain of Penicillium patulum. Experientia 1972, 28, 1252.

(33) Ferrer, E.; Juan-García, A.; Font, G.; Ruiz, M.J. Reactive oxygen species induced by beauvericin, patulin and zearalenone in CHO-K1 cells. Toxicol. in Vitro 2009, 23, 1504-1509.

(34) Fliege, R.; Metzler, M. Electrophilic properties of patulin. Adducts structures and reaction pathways with 4-bromothiophenol and other model nucleophiles. Chem. Res. Toxicol. 2000, 13, 363-372.

(35) Wallen, L. L.; Lyons, A. J.; Pridham, T. G. Antimicrobial activity of patulin derivatives: a preliminary report. J. Antibiot. 1980, 33, 767-769.

(36) Singh, J. P. In Antibiotics; Gottleib, D., Shaw, P. D., Eds.; Springer-Verlag: New York, 1967; Vol. I, pp 621-630. 